Divan Edebiyatı Araştırmaları Dergisi 10, İstanbul 2013, 205-228.

\title{
YAŞAR AYDEMIR*
}

\section{Makedonyalı Saîd ve Şiirleri}

\author{
Sa'id of Macedonian and His Poems
}

\section{Ö Z E T}

Osmanlı kültür coğrafyasında belli bir zihinsel ve estetik anlayışın yönlendirdiği, değişen zihinsel süreçlere paralel olarak kendisini yenileyen Türk edebiyatı Osmanlı coğrafyasının her bölgesinde temsil edilmiştir. Ana karakter değişmemekle birlikte bölgelerin içinde bulunduğu şartlara göre farkl tonlara bürünen söyleyişler zaman içerisinde bölgelere ait üslupları görünür kılmıştır. Söyleyişteki Rumeli üslubu bunlardan birisidir.

Yazıda Makedonya Millî Kütüphanesi (Narodna İ Univerzitetska Biblioteka Skopje) OMCT I/150 numarada kayıtlı bir cönkte şiirleri bulunan Saîd'in şairliği ve şiirleri konu edilmiştir. Osmanlının son döneminde, bugünkü Makedonya sinırları içerisinde bulunan Kalkandelen ve Gostivar şehirleri civarında yaşamış olan Saîd, Bektaşîliğin ağır bastığı bir kültür coğrafyası içerisinde yetişmiştir. Şiirlerinde umumi olarak tasavouf, özel olarak da Bektaşilik kültürünün izleri görülür. Bunun yanında şehirlere ve köylere dair gözlemleri; tasvirleri, değerlendirmeleri ve şiirlerinde şehir tarihini ilgilendirecek nitelikte malzemelerin bulunması onu önemli kllmaktadır.

Makalemizde Saîd'in şiirlerinin öne çıkan taraflarının altı çizilmiş; dili kullanımına, vezin ve konu tercihlerine, kullandı̆̆ı nazım şekillerine dikkat çekilmiştir. Şairin Türk edebiyatı içerisindeki durduğu yere ait çıkarımlarda bulunulmuştur. Şiirlerinden seçilen birkaç örnekle yazı tamamlanmıştır.

\author{
A N A H T A R K E L İ M E L E R
}

Saîd, Cönk, Kalkandelen, Gostivar, Bektaşî, Şiir

\author{
A B S T R A C T
}

Turkish literature, which was forged by a certain aesthetic and cognitive understanding in the Ottoman cultural territory and renewed itself in accordance with cultural transformations, was represented in every region of Ottoman geography. Utterances, cast under the impact of local varieties, have taken the form and spirit of the area where they sprang forth and rendered the form of utterances visible while the main character was exposed to no dramatic alteration. Rumelian mode in the utterances is one of the examples.

What this paper dwells on is the poems and poesy of Saîd the poems of whom were found in the OMCT I/150 cönk registered in Macedonia National Library (Narodna I Univerzitetska Biblioteka Skopje). Saîd, who lived in the cities Kalkandelen and Gustivar currently within the borders of Macedonia in the last periods of the Ottoman Empire, was brought up in a social circle in which Bektashism predominated. In his poems, the imprints of Sufism publicly and the culture of Bektashism individually are observed. The cities and villages of observation; descriptions, reviews and the materials which concern the history of the city in his poems make him significant.

In our article, prominent sides of Saîd's poems were emphasized; the use of language, his preferences of rhythm and subject and poetic forms which he used, have been pointed out. Some inferences about the literal position of the poet in Turkish Literature were made. The study was completed with a few selected examples of his poems.

K E Y W O R D S

Saîd, Cönk, Kalkandelen, Gostivar, Bektashism, Poem.

\footnotetext{
" Prof. Dr., Gazi Üniversitesi Gazi Eğitim Fakültesi Türk Dili ve Edebiyatı Anabilim Dalı, Ankara (yasaraydemir@yahoo.com).
} 


\section{SAÎD VE ŞIIIRLERİ}

\section{Hayat1}

Saîd'in doğum tarihine dair bir bilgimiz yoktur. Şair tezkirelerinde kendisine yer bulamamış şairlerimizdendir. Onun hakkındaki bilgilerimiz şiirlerindeki bilgi kırıntılarının bir araya getirilmesinden ibarettir. Şairin nasıl bir eğitim aldığı, ne işle uğraştığına ilişkin de bir bilgimiz yoktur. Saîd'in şiirleri içerisindeki en eski tarih şeyhi Abbas Baba'nın ölümü münasebetiyle yazdığı tarih manzumesidir. Mürşidi Abbas Baba 1218/1803-04 tarihinde vefat ettiğine göre Saîd bu dönemde şiir yazacak ve tarih düşürecek kadar bir birikime sahip olmalıdır. Bu hususlar dikkate alındığında şairin doğumunun en geç 18. yüzyılın ikinci yarısında olduğunu söylemek yanlış olmaz. Saîd'in Farsça şiirlerinin de olması şiir yazacak kadar Farsça bilgisine sahip olduğunu gösterir. Dolayısıyla şairin içinde bulunduğu gelenek içerisinde de olsa belli düzeyde eğitim aldığını söylemek mümkündür.

Saîd şiirlerinde genellikle aruz veznini tercih etmiş, kimi zaman da hece ile şiirler yazmıştır. Üslubunda klasik şiirin genel havasının etkisi görünse de zaman zaman karşılaştığımız vezin hataları, kafiye problemleri şairin klasik edebiyat kültürüne dair gelenek içerisinde ve çevresinden edindiği bilgi ve yönlendirmelerin dışında özel bir eğitim almadığı yönündedir.

Saîd'in Kalkandelen, Gostivar, Serakin, Palçiste gibi yerlere dair yazdığı şehrengiz tarzı şiirlerinden bu bölgede yaşadığı çıkarımını yapabiliriz. Coğrafi olarak Kalkandelen, Gostivar, Palçiste ve Serakin birbirine çok yakın yerleşim yerleridir. O dönem içerisinde Kalkandelen ve Gostivar bugünkü gibi büyük yerleşim yerleridir. Serakin ve Palçiste daha küçük yerleşim yerleri, hatta köylerdir. Muhtemeldir ki şairimiz bu köylerden birisinde doğmuş, gerek tarikat ilişkileri ve gerekse başka münasebetlerle Kalkandelen ve Gostivar'a gidip gelmiş belki de oralardan birisine yerleşmiştir.

Saîd'in ne kadar bir süre hayatta kaldığı konusunda da elimizde net bilgiler yoktur. Şairin şiirleri içerindeki en son tarihler 1232/1816-17'yi 
göstermektedir. Bunlardan birisi Recep Paşa'nın Serakin'de Vardar nehri kenarına yaptırdığı kaldırım münasebetiyle yazdığı tarih manzumesidir:

Bu hayrât oldr çün itmâm gelüp târîh dir erkâm

Paşadan oldı çün in 'âm safâ irdi kamu câna Sene 1232/1816-17

Aynı tarihe rast gelen ikinci manzume de Vardar Nehrinin taşması sonucu Serakin'i su basmasını konu alan manzumedir:

Sâl-i Sa îdden târîh dilerseñ

Ebced hisâbrndan bul haber var 1232/1816-17

Buna göre şairin 1232/1816-17 yıllarında hayatta olduğu anlaşılmaktadır. Klasik gelenek içerisinde şairlerin şiirlerinde yaşlılıklarını ima edecek birçok bilgi bulunur. Buradan hareketle ihtiyatla da olsa bir çıkarım yapılabilir. Ancak Saîd'de böyle bir imaya da rastlanmamaktadır. Yine savaşlara ve huzursuzluklara dair bir bilgi de yoktur. Recep Paşa'nın ölüm tarihi 1238/1822 olup mezarı Harabâtî Baba Tekkesinde'dir(Kalafat 1998: 87). Saîd'in kendisinden yardım gördüğü, şiirleri içerisinde müteaddit defalar onun adını andığı halde onun ölümünden söz etmemesi şairin 1238/1822 tarihinden önce ölmüş olabileceğini düşündürüyor.

Saîd, yaşadığ1 dönemde bu bölgede etkin olan Recep Paşa'nın ve ailesinin yardımlarını görmüştür:

Bulardur hâfiz-ı belde sezâlar medhe her dilde

Kılarlar hıfzı her yirde nazar ile nigehbâne

Egerçi zâhirâ her ân irer in 'âmları ey cân

Velî Hak'dan bize ihsân bulardur bak bu seyrâna

Hasendür bunlaruñ kârı kılarlar mazluma yâri

Kıla 'aon-i ebed Bârî ireler lutf-ı Yezdân'a

Yukarıdaki dizelerde ferdi olmasa da umumi bir memnuniyetin dile getirildiği Recep Paşa ve sülalesi için, şairin Gostivar şehrinin medhinde kaleme aldığı manzumesinde daha açık bir ifade ile Recep Paşa'nın kendisinin koruyucusu olduğunu ifade etmektedir: 
Tâli 'üñ gülmiş Sa îd hamd eyle Hakk'a her zamân

Hâfiz olmışdur saña Receb Paşa ol 'âlî-şân

Tâ kıyâmet ırk-ı pâki bulmaya aslâ ziyân

Her yire olmaz nasîb dâd-ı Hudâ 'dur Gostivar

Şair Kalkandelen şehrinin medhine ayırdığı manzumesinde de Recep Paşa'nın Kalkandelen'i adaletle süslediğini ifade ile ondan övgüyle söz etmiş ve soyunun orada ebedi kalmasını dilemiştir:

İftihâr it gel senüñle Rûm ili çıkmaz başa

Eylemişdür 'adl ile tezyîn seni Receb Paşa

Ni 'metüñ bezl eylemiş insâna hayvâna kuşa

Irk-ı pâki câvidân olsun saña Kalkandelen

Sonuç olarak Saîd'in 18. yüzyılın ikinci yarısı ile 19. yüzyılın başlarında hayatta olduğu anlaşılmaktadır. Doğum ve ölüm tarihlerine ait net bilgilerimiz olmasa da ölüm tarihinin 1817-22 yılları arasında olması kuvvetle muhtemeldir. Şiirlerinden bir derviş olduğu anlaşılan Saîd Kalkandelen, Gostivar şehirleri havalisinde yaşamıştır. Devrin yöneticisi Recep Paşa ve ailesinden yardım görmüştür.

\section{Tarikatı}

Saîd mutasavvıf bir şahsiyettir. Bektaşî geleneğine bağlı bir sufidir. Bunu şiirlerinin neredeyse tamamında görmek mümkündür. Şairin şiirlerinin bulunduğu cönkte yer alan başı eksik ilk manzume 14 Masum İmamın övgüsüne ayrılmıştır. 4. şiiri de aynı çerçevede yazılmış dokuz Masum İmamı konu alır. Kalenderî başlığını taşıyan ikinci manzume; karşılaştığı, ona bağlanmamışsa bile sohbetini dinlediği, belki de aynı sohbet halkasında örnek aldığı İbrahim Dede'ye övgü niteliğindedir. Üçüncü manzume sufiyane bir gazeldir. Beşinci manzume şeyhi Abbas Baba'nın ölümüne düşürülen tarih manzumesidir. 6. şiir 11'li hece ölçüsüyle müzdeviç murabba nazım şekliyle yazılmış 7 bent tutarında, bir kurgu ile muhtemelen hayatında gördüğü veya tarikat silsilesindeki "Baba"ları yad eden bir manzume niteliğindedir. 10. manzume müzdeviç murabba nazım şekli ve 11'li hece ile yazılmış Şeyh Maksud Baba'yı anlatan bir şiirdir. 13. manzume Sersem Ali Baba Dergâhı Bab-1 Hırmen Kapı- 
sı üzerindeki köşke düşülmüş tarih manzumesidir ki bu da tarikatı ve gönül verdiği dergâhındaki bir yapıyı konu alır. 23 numaralı "semai" başlığını taşıyan gazel formundaki manzume de mürşit arayışını veya mürşide bağlılığ1 öğütleyen bir manzume özelliği taşır. 26. manzume gazel formunda ve tasavvufî düşünceyi merkeze alan bir şiirdir. 27. manzume de benzer bir özellik taşır.

Saîd'in Abbas Baba'nın ölümüne yazdığı tarih manzumesinde kendine hitaben "mürşidüñ târîhini" dediğine göre Şeyh Abbas Baba Saîd'in şeyhi olmalıdır:

Ey Sa îdî söyle dilden mürşidüñ târîhini

Maksada irdi revânı şâd bula 'Abbas Baba Sene 1218/1803-4

Abbas Baba muhtemelen Saîd'in ilk mürşididir. Hece ile yazdı̆̆ 1 müzdevic murabbaında yaşadığı bir hali anlatırken;

Görince ta zî̀ma kıldık kıyâmı

'Aceb kimdür didük bunuñ imâmı

Anı gördüm göñü̈mün dilârâmı

Şeyh Eyyûb Efendi kendidür geldi

dizeleri Saîd'in şeyhinin vefatından sonra tabi olduğu bir başka ismi hatıra getirir. Şeyh Eyyub Efendi'yi "gönlümün dilârâmı" olarak tanımladığına göre bu isim muhtemelen kendisine tabi olduğu veya tarikatta bir ortaklıklarının bulunduğu bir isimdir. Şeyh Eyyub Efendi'nin kimliğine dair de şair "Şeyh Mustafa Baba'nın gevheri", "Pîr Adulkadir'in gonca gülü", "Şeyh Abbas Baba'nın gönül sırrı", "Prizren Kadirî Dergâhı sahibi" bilgilerini verir. Şeyh Eyyub Efendi, "Şeyh Abbas Baba'nın gönül sırrı" olduğuna göre Saîd'in ondan icazetli olması da muhtemeldir.

Erenlerden budur niyâzum her-gâh

Himmetleri olsun Sa îde hem-râh

Şehr-i Pirizren'de sâhib-i dergâh

Tarîk-i Kadrî'nü̃ bir şâh[i] geldi

Saîd'in Maksûd Baba methine yazdığı müzdeviç murabbadan Maksud Baba'nın Kalkandelen'de Kadirî Dergâhının kurucusu, keramet sahi- 
bi, ledün ilminin dalgıcı, Köprü Camii'nde dört yıl misafir kalmış, dört yıl Rapçiçe Camii'nde riyazeti olan, Köprü kurbünde medfun bir zat olduğunu öğreniyoruz. Buradan hareketle şairin Kadirîlikle ilişkisi üzerinde düşünmek gerekmektedir. İhtiyatla onun Kadirîliğe de intisabına dair bir kayıt düşülebilir.

Saîd'in Kalkandelen methine yazdığı şehrengiz tarzındaki murabbaında şehirde bulunan, muhtemelen tanınmış tarikat büyüklerinden söz etmektedir. Ancak bu isimlerin bir kısminın hangi tarikata veya tarikatlara bağlı isimler olduğunu bilemiyoruz.

Şairin kalenderi başlıklı bir şiirinde de İbrahim Dede methedilmiştir. Şairin satır arasında verdiği bilgiden İbrahim Dede'nin, şairin meclisine gidip geldiği, üstat bildiği etkileyici bir isim olduğu anlaşılmaktadır. Ancak bu ismin de tarikatına dair bir bilgimiz yoktur.

\section{Edebî Kişiliği}

Şairin elimizdeki cönkte irili ufakl1 36 manzumesi vardır. Cönkte bulunan bir rubaînin başında "Rübâî-i Nazmî Efendi" kaydı vardır. Diğer manzumelerin ya mahlas beyitlerinde Saîd'in adı geçmekte veya mahlas geçmeyen şiir veya şiir parçası varsa da aksine bir isimlendirme bulunmamaktadır.

Saîd, bugün Divan şiiri ve halk şiiri olarak gruplandırdığımız, temelde aynı geleneğe yaslanan iki şiir üslubumuzun ortasında yer alan bir şair profili çizmektedir. Hem aruz hem hece veznini kullanmıştır. Klasik Türk edebiyatı nazım şekillerinden gazel, kaside, kıta, murabba, rubaî gibi nazım şekilleri yanında Halk şiirine ait koşma nazım şekli, destan, kalenderî, semâî, tecnis gibi şekil ve türlere de yer vermiştir.

Saîd'in şiirlerinde kullandığı dil, devrine göre sade bir dildir. Rumeli ağzını yansıtır. Tekid için "be" kullanımı Rumeli ağzında yaygındır. Saîd'in şiirlerinde de bunlar fark edilir derecededir:

Be san girdâb idi ey cân bu yerd[e] menfez-i kervân

Virürdi zahmeti her ân geçen insâna hayvâna 
Hoş nazar itmiş ezelden şânına ol zü 'l-kemâl Eylemiş tezyîn her yanuñ senün sâhib-cemâl Kudretinden câri ırmağlar be san âb-ı zülâl Ger saña mânend yok dirsem sezâ Kalkandelen

Elinde tesbîh-i hâcı güyâ bir yükde yok bacı Göt ararsañ be helvâcı kapu ardı pazaruñ var İsitse zâni sözüni çeker takvâya özüni Be bulsun konşı kızını görürdi ne pusaduñ var

Şairin Rumeli ağzı bu söyleyişlerle sınırlı kalmaz. Aruzla yazdığı bir şiirde "söyler" olarak imla edilen kelimeyi "süler" okuyup vezne uydurur:

Açar ağzın pelîd ahmak süler sözi kamu lak lak

Başına on iki tokmak yaraşur armağanuñ var

Aşağıya alınan örnekte de "değil" kelimesinin imlasını "dîl" okunacak biçimde yazar:

Bir seher vakti müyesser olsa gelse yanuma

Hoş terahhum eylese işbu dil-i sûzânuma

Dilesem hâl arz idem mahfî benüm sultânuma

Bilürem ă̆yâr aradan hâli dîl bilmem neden

Saîd'in şiirlerinde hem aruz hem de hece veznini kullandığını yukarıda ifade etmiştik. Zaman zaman vezin kusurları olsa da bunu şairin çok da kusur olarak değerlendirmediğini söylemek mümkündür. 11'li hece ölçüsü ile yazdığı bir şiirde herhangi bir mısrada hece sayısının 10'a düşmüş olması veya 12'ye çıkmış olması normaldir. Aşağıya alınan metinde ikinci mısra ile diğer bendin ikinci mısraları buna örnek teşkil eder. İkinci dörtlüğün üçüncü misraindaki "köprü" kelimesinin "köpürü", -ki bu Rumeli ağzında normaldir- dördüncü mısradaki "Şeyh" kelimesinin de medli okunması hece sayısını eşitler niteliktedir. Şairin buna benzer kullanımlarının başka örnekleri de vardır. Daha çok aruz vezninden alışık olduğumuz medli okumanın hece ölçüsünde hece sayısını eşitlemek için kullanılmış olması da dikkat çekicidir:

Câmi '-i Rapçiçe makarr[1] tekrâr

Girü dört sene riyâzeti var 
Inâyet eylemiş ol ganî Hudâ

Tarîk-i mustakîme gelmiş reh-nümâ

Köprü kurbinde makâm-ı me'vâ

Cây-ı dil-güşâ Şeyh Maksûd Baba

Saîd, beş şiirde hece ölçüsünü tercih etmiş olup tamamı 11'li hecelidir. Bir başka husus da hece vezninin tercih edildiği şiirlerin hepsi nazım birimi bent olan murabba nazım şekli olmasıdır. Bunlardan ikisi murabba, biri tecnis birisi de destan başlığını taşır. Bir manzume de başlıksızdır. Söz konusu şiirlerin tamamı uzun tasvirlere ayrılmıştır.

Şairin tek beyitli nükte, cevap gibi şiirleri de dâhil olmak üzere şiirlerinin 31'inde aruz tercih edilmiştir. Bunların 13'ü “Mefâîlün mefâîlün mefâ̂̂lün mefâîlün" kalıbıyla yazılmıştır. Bu kalıbın 13'ünün 10'unda ortadan ikiye bölünebilen musammat biçim tercih edilmiştir. Bu da şiirlerin ahengini artırmıştır. Kimi beyitlerde veznin ritmi muhtevaya uygun bir ses haline de dönüşmüş görünmektedir:

Cihânda niçeler cânâ bulunur 'âlim ü dânâ

Kamuyı Hak bilüp ammâ dilü̃ ferd eyle ferd eyle

"Fâilâtün fâilâtün fâilâtün fâilün" kalıbı beş şiirde tercih edilmiştir. Bunlardan üçü murabba nazım şekliyle olup ikisi şehir övgüsüne ayrılmıştır. Bu kalıbın kullanıldığı iki manzume de tarih manzumesidir. "Mefûlü mefâîlü mefâ̂lü feûlün" kalıbı dört şiirinde tercih edilmiştir. Birisi Farsça bir gazelde, üçü de "kalenderî" başlıklı şiirde tercih edilmiştir. Veznin ritmi özellikle "Kalenderî" başlığını taşıyan cönkteki 24 numaralı şiirde muhteva ile örtüşmüş görünüyor. Şiirde redifin de desteklediği hareketlilik veznin duraklarıyla daha bir görünür hale gelmiştir:

Bir ince miyân serv-i revân şâha sataşdum

Benleri siyâh ruhları gülzâra sataşdum

"Mefûlü mefâîlün mefûlü mefâillün", "Mefûlü fâilâtün mefûlü fâilâtün" kalıpları ikişer kez "Mefâilün feilâtün mefâilün feilün" kalıbı da üç kez kullanılmış olup tek beyitli nükte ve cevaplarda tercih edilmiştir. Nüktenin vezni ne ise cevabın vezni de odur. Veznin durakları ve hep- 
sinde tefilelerin iki kez tekrarı aynı uzunluktaki soru ve cevabı ile ritmik olarak da uyuşmaktadır:

Yeldâ gicesi birdür bir yılda olur peydâ

Bu nice 'alâmetdür bir ayda iki yılda

\section{Cevâb-ı Sa îd be Zebân-ı Fârisî}

Rûyeş mâh-ı tâbânveş dilhâ râ koned şeydâ

Ber ârız-ı ân mâh-rûy mûyeş çü şeb-i yeldâ

Şairin vezin tercihleri içerisinde birer kez de "müstefilün müstefilün" ve "feilâtün feilâtün feilâtün feilün" kalıbı yer almıştır.

Şairimizin şiirlerinde kimi galat kullanımlar da dikkatimizi çeker. Aşağıdaki beyitte mısra sonunda yer alan "ey dilâ" söyleyişi Türkçe açısından doğru bir kullanım değildir. Zaten "dilâ" kelimesinin sonundaki uzun "â" harfi "ey" anlamina gelmektedir. Bu haliyle "Ey, ey gönül!" gibi bir anlam çıkar ki standart Türkçe açısından yanlış bir kullanımdır:

Gel Sa îdî dilde târîh söyle çün buldı vücûd

Böyle bir kasr-ı müferrih medhe lâyık ey dilâ

Aşağıya alınan beyitte de "her seherde" yazılmasını beklediğimiz kelime, vezin de dikkate alınarak "her seherlerde" olarak imla edilmiştir:

San hizâsında nesîmüñ bu makâm-ı dil-pezîr

Her seherlerde ziyâret eylemekde dâ'imâ

Saîd'in şiirlerinde sağlam bir kafiye olduğunu söylemek zordur. Bunun bir kısmı muhtemelen devrin anlayışından gelen, benzer seslerin birbiriyle kâfiyelendirilmesinde bir beis görülmemesi temayülüdür. Aşağıya alınan beytin iç kafiyesi "n" iken iç kafiyeyi oluşturan sesin birisi "öñde" kelimesinde "ñ" haline dönüşmüştür:

Şıhuñ anbârıdur öñde güzel bir cây-ı ferhunde

İür 'âşıklara anda ferah-efzâ-yı Palçiste

Aşağıya alınan sekiz beyitli manzumede sağlam bir kafiye olmadığı gibi altı beytinde "-ından" sesleriyle oluşan redifin iki beyitte "-ümden" ve "-amdan" haline dönüştüğü görülür: 
Çün kavs-i kuzah ebrûların yây idüp ol şâh

Tîr ile urup zâr iderüm rîş-i dilümden

Bülbül gibi feryâd iderem ol güli görsem

Zülfini nikâb eylemiş âh ceor elinden

İsmini Sa îd yâda getür şâh-ı cihânuñ

Sab ismi ile add ide gör yâri rakamdan

Kimi örneklerde redif öncesinde sağlam bir kafiye yoktur. Takip eden manzumenin redifi "-dan sor", kafiyesi de "-ân"dır. Ancak üçüncü beytin redifi öncesinde kafiyeyi oluşturan "-an" yoktur. Bunun yerini "-âl" almıştır.

Dilerseñ râh-ı takvâyı bulup bir vâ izândan sor

Velî dil 'ilmini âgâh olan sâhib-dilândan sor

Bilem dirseñ bu esrârı degüldür herkezin kârı

Dimişler Mantıku 't- Tayr'ı Süleymân-ı zamândan sor

Degüldür sarf u nahv ile dahi 'ilm-i ma âniyle

Bulunmaz kîl u kâl ile yine bir ehl-i hâlden sor

Aynı durum "bilmem neden" redifli müzdeviç murabbada da vardır; bir bendinde "-ur" bilmem neden"(20/1) kafiye ve redifi olması gerekirken bir diğer bendinde "göñül bilmem neden" (20/3), bir diğerinde "-güşâ bilmem neden"(20/4) haline dönüşmüştür. Bunların örneklerini çoğaltmak mümkündür.

Şiirlerin imlasında dikkati çeken bir başka husus da "ñ"/"n" kullanımlarının tutarsızlığıdır. "ñ" yazılması gerekirken "n" yazılması bir ölçüde anlaşılabilir bir durumdur. Çünkü yazı dilindeki muhafazakârlık konuşma dilinde yazı dilindeki kadar yoktur. Buna rağmen konuşma dilindeki bu kullanım sıklığı bir süre sonra yazı dili haline dönüşür. Günümüze yaklaşan o dönemin imlasında bu tür değişimlerle yavaş yavaş "ñ" yerini "n"ye bırakmaya başlamıştır. Ancak "n" harfi ile gösterilmesi gereken kimi yazımlarda "ñ"nin tercih edilmesi anlaşılması zor bir durumdur. 18 ve 19. asırlara ait başka metinlerde de rastladığımız bu husus şairden mi müstensihin acemiliğinden mi yoksa umumi bir özensizliğin sonucu mudur, net bir karara varmak zordur. Aşağıya alınan örnekte ilk kelime 
metinde "dilersin" biçiminde imla edilmiştir. Doğrusu ise "dilerseñ" olarak imla edilmesidir:

Dilerseñ râh-ı takvâyı bulup bir vâ izândan sor

Velî dil 'ilmini âgâh olan sâhib-dilândan sor

Bunun tersi bir durum ise "etrâfın" olarak imla edilmesi gereken kelimenin "etrâfuñ" okunacak biçimde yazılmış olmasıdır:

Tuna menendi oldı vü taşdı

Etrâfın aldı ol nehr-i Vardâr

Saîd, tür olarak medhiye, hicviye, şehrengiz, destan gibi hem klasik Türk edebiyatı hem de halk edebiyatında da karşılık bulan konulara değinmiştir.

Şiirlerinin büyük bölümü tasavvufî neşve ve amaçla kaleme alınmıştır. Kişi medhiyelerinin tamamına yakını kendi döneminde veya muhitinde yaşamış isimlere ayrılmıştır. Recep Paşa övgüsünde bile şairin hareket noktasını onun hal ehli oluşu, başta Harabatî Baba Tekkesi olmak üzere tarikat mekânlarına farklı şekillerde desteği oluşturur.

Birisi baştan eksik iki mazume 14 Masum İmamın övgüsüne ayrılmiştır:

İmâm-ı evvel ol şâh-ı velâyet sâki-i Kevser

Dinildi lâ-fetâ medhinde bir nûr-ı Hüdâ'dandur

Gözüm nûrı benüm mutlak Hüseyn-i ber-güzîd ol şâh

Yezîd'e la 'netüm her dem o kahr-ı Kerbelâ'dandur

Felekde neyyirân şermende vech-i pür-ziyâsından

Dilüm mihriyle tezyîn olduğı Zeyne'l-abâ'dandur

Mukırrem cân u dilden men garîb zât-ı a lâya

Rizâya ser-nihâdum var 'Ali Mûsî Rızâ'dandur

Tasavvufî neşve müstakil diğer şiirlerinde de kendisini gösterir. Bazı beyitlerinden örnek alınan aşağıdaki şiir de hem tasavvufî hem de nasihat barındıran bir üslupla kaleme alınmıştır: 
Cihânda niçeler cânâ bulunur 'âlim ü dânâ

Kamuyı Hak bilüp ammâ dilüñ ferd eyle ferd eyle

Kelâm-ı mürşidi gûş̧ it bulup zevkı dilüñ hoş it

Muhabbet câmın nûş itmege cehd eyle cehd eyle

Dime kim mürşidün yokdur mürebbüñ zât-ı mutlakdur

Kamu esrârı pür-Hak'dur yedi bend eyle bend eyle

Saîd'in şiirleri içerisinde şehrengiz tarzı manzumeleri de önemli bir yer tutar. Şehir tarihi ve kültürü açısından önem arz eden bu şiirlerde Kalkandelen, Gostivar şehirleri ile bugün de birer köy olan Serakin ve Palçiste'nin coğrafi, tabii güzellikleri ve buralarda bulunan önemli şahsiyetlerin isimleri anılmıştır. Müzdeviç murabba nazım şekliyle ve aruz vezniyle yazılan Kalkandelen medhiyesi 16 bentten oluşur. Başlangıçta şehrin tabii görüntüsü, arkasından da tarihî ve kültürel hayatı yansıtan; daha çok tasavvufî kimlikleriyle öne çıkmış isimlerin mezarları ve kendince şehre katkılarını gösteren bir manzumedir:

Mazhar-ı lutf-ı Hudâ'dur bil dilâ Kalkandelen

Mirsad-ı sıdk u safâdur 'âşıka Kalkandelen

Menba'-ı nûr-ı şerî'at medhal-i sirr-ı tarîk

Mahzen-i genc-i hakîkat ârifâ Kalkandelen

Hoş nazar itmiş ezelden şânma ol zü 'l-kemâl

Eylemiş tezyîn her yanuñ senüñ sâhib-cemâl

Kudretinden câri ırmağlar be san âb-ı zülâl

Ger saña mânend yok dirsem sezâ Kalkandelen

Nev-bahâr faslı irişdükde açılur gülleri

Her yañadan zâr idüben ötüşür bülbülleri

Cümle etrâfı mesîregâh müferrih yerleri

Her ne deñlü medh iderlerse revâ Kalkandelen

Bir 'aceb münbit-i sahrâ yir kamu halk toyunur

Nâmı dillerde bahâdırlıkla dâ'im söylenür

Böyle bir sahrâsı hem var belde nâdir bulunur

Kırk iki dirler zemînüñ arzına Kalkandelen 
Bir yañadan hâfizudur Şâh 'Ali Sersem Baba'

Sûy-ı bâlâda nigehbânuñ durur Koyun Baba ${ }^{2}$

Bir yañadan âsımuñ hâcet-revâ Yarar Baba

Himmet-i merdân bilüpdür dilberâ Kalkandelen

Şehirde söz konusu edilen isim sayısı Kalkandelen kadar olmamakla birlikte benzer bir kompozisyon şairin Gostivar medhiyesinde de vardır. Buna göre Gostivar, insana mutluluk ve safa veren bir yerdir. Âşıkların gönlünü açar. Dört bir tarafı ziynetle dolu, İrem bağını andıran, gönül çeken, bahçeleri dolu, bütün ağaçları gölgeliktir. Çiçek mevsimi gelince her tarafı hoş bir kokuyla dolu, her yeri mesirelik, her sokağı kuşların ötüştüğü, ırmakların çağladığı bir yerdir. Salı günleri pazarı kurulur. Şahin Bey'in sarayı dikkat çekicidir. Zengin yoksul herkes orada doyar. Hüseyin Bey onun soyundan gelmiştir. Hanedanın muhibbidir:

Ey göñül bir cây-ı hürrem pür-safâdur Gostivar

'Âşık-ı dil-besteye hoş dil-güş̧âdur Gostivar

Çâr etrâfı müzeyyen sanki bir bâg-ı İrem

Nâzır-ı âsâr-ı Hakk'a hoş-likâdur Gostivar

Mevzi'-i dil-keş dil-âvîz bir mekân-ı muhtasar

Ravzalar memlû kamu gelmiş dirahtân sâye-ver

Mevsim-i ezhâr iricek dilleri hûş-bû ider

Böyle bir zîbâ dilâ nâzik edâdur Gostivar

Hep mesîre-gâh her sû bir mahall-i murgzâr

Kudret ile câri olmış her yanadan cûy-bâr

Cem'olur her hafta se-şenbe güni anda pazar

Medh olur dâd u sitedde râyegândur Gostivar

${ }^{1}$ Şah Ali Sersem Baba aslında Necef'te medfundur. Müridi ve kullarından olan Harabatî Baba, Koyun Baba, Kızıl Baba, Yarar Baba ve Ballı Baba adındaki arkadaşlarıyla Kalkandelen'e gelir. Harabatî Baba burada kalır ve bir yerde bir kandilin yandığını fark eder ve bunun kendini belli eden Sersem Baba'nın ruhu olduğunu farz ederek onun adına bir mezar ve üzerine de türbe yaptırır. Bu türbenin olduğu yere Harabatî Tekkesi inşa edilir (Kalafat 1998: 86).

${ }^{2}$ Kalkandelen Şipkovitsa köyünde Koyun Baba Tekkesi vardır (Kalafat 1998: 85).

${ }^{3}$ Kalkandelen Poroy köyünde Yarar Baba Tekkesi vardır (Kalafat 1998: 85). 
Hoş binâ kılmış Şâhin Beg anda bir' âlî sarây Bir 'aceb cây-ı teferrüc dil-sürûrı cân-fezây Ni met ü ikrâm bulur anda gelen yohsul u bây Şöhret içre ol saña bir yüce şândur Gostivar Anuñ ırkından Hüseyn Beg gelmiş ol 'âlî-cenâb Sıdk ile cân u göñülden bende-i Eb̂̀-turâb Çün muhibb-i hânedândur eyleye Hak kâm-yâb Ekseri dil-bend-i râh-ı Mustafâ'dur Gostivar

Şehrengiz formatında övgüsü yapılan bir başka şiir Serakin'in mehdine ayrılan gazel formundaki şiirdir. Manzume 23 beyittir. Anlatımına göre şair bir bahar günü kuşluk vaktinde Serakin'e varmıştır. Etraftaki çemenlerin görüntüsü döşenmiş yeşil halı gibidir. Her tarafta ağaçlar, etrafı kuşatan akarsular, bir yanında durmaksızın akan Vardar nehri. Orada sakin olanlardan birisi Fahri Yuşan'dır. Kâmil bir insan olan Yuşan tarikatta akranları içerisinde öne çıkan rehberdir:

Duhâ vakti süvâr olduk ol âlî râha yüz sürdük

Sürûr ile revân olduk öterdi çevre bülbüller

İrişdük şol yire ey yâr ki her dem göñül arzîlar

Kamu etrâfa çemenzâr döşenmiş sebz hâlîler

Degüldür vasfin imkân teferrücgâh her irfân

Ne yaña eyleseñ seyrân irür bir gûne cümbüşler

Donanmış her yaña eşcâr ihâtâ eylemiş enhâr

Kuşatmış bir yanın Vardar gice gündüz akup çă̆lar

...

Birisi Fahri Yûşân'dur ki ol kâmil-i insândur

Mufaddal beyne l-akrândur tarîkatda odur rehber

Saîd'in şehrengiz türü şiirlerinden birisi de varak kaybından dolayı sonu eksik bir manzume olan Palçiste övgüsüdür. Palçiste, şen bir yerdir; mahzun gönüllere safa verir. Yüksek bir yer olması hasebiyle her insanın seyirlik yeridir. İçinde mescid ve minber bulunur, ezberden hutbeler okunur. Önde Şeyhin ambarı vardır. Palçiste'nin çiçekleri gönülleri hoş koku ile doldurur: 
'Aceb bir mevzi 'i hurrem dilâ bu cây-ı Palçiste

Dil-i mahzûnlara hem-dem safâ-bahşâ-yı Palçiste ${ }^{4}$

Mekân-ı mürtefi 'ey cân kılur etrâfli] hoş seyrân

Teferrucgâh-ı her insân kenâr-ı cûy-ı Palçiste

İçinde mescid ü minber okunur hutbeler ezber

İder ta lîm ma sûmlar güzeldür rây-ı Palçiste

Şıhuñ anbârıdur öñde güzel bir cây-ı ferhunde

İür âşıklara anda ferah-efzâ-yı Palçiste

Çekilmiş ravzalar memlû dirahtân sâye-ver dil-cû

Kılur her dilleri hoş-bû dilâ ezhâr-ı Palçiste

Saîd'nin şiirlerinin yelpazesi geniştir. Bir taraftan tasavvuf ağırlıklı şiirler kaleme alırken bir taraftan da laubaliliğe varan ifadede şiirleri vardir:

Hüdâ kılsa dilâ lutfı bulurdum bir áceb zeoki

Ki gül bâğında gül vakti gülinden gül direr olsam

Ne hoşdur ey göñül şol dem hicâb ref' eylese yârüm

Lebiyle leb lebe bir dem leb-â-leb ber murâd olsam

Veya yeme içme arzusunu dile getiren, nasıl bir terkiple hazırland1ğını da ifade eden şiirlerine rastlanır;

Tatlu yahni hoşdur boyun etinden

Pür iştihâ alsam koç bumbarından

Soğan dolma közi haddi zâtından

Pirinç ile anı tıklamış olsa

Muhallebi aşı göñlüm dură̆ı

Badılcan silkmesi üzdürse yağı

Südli pirinç bir hoş tutsa kaymă̆ı

Su sığıı südünden kaynamış olsa

${ }^{4}$ Makedonya'da Tetova (Kalkandelen)'ya bağll, Şardağları'nın eteğinde bir köyün adıdır. 
Bir şiirinde de onun hiciv yönünü görürüz:

Behey münkir bize ta in itmeden bilmem ne kâruñ var Dilüñ şetm eylemekde dâ'imâ bir özge hâlüñ var

Ne cürmüm var saña bilmem anaña sögmedüm bir dem

Geçer aylar yüzin görmem di bizden ne zarâruñ var

Ol ağzuñ kim senüñ söyler ananuñ fercine beñzer

Akar dürlü necâsetler özüunde böyle dâdın var

Açar ağzın pelîd ahmak süler sözi kamu lak lak

Başına on iki tokmak yaraşur armağanuñ var

...

Sanur özini kıldı pâk durur tâ atde o bî̀-bâk

Cenâbetsin behey nâ-pâk cühûddan bir tamaruñ var

Saîd'in şiirlerinde dikkat çeken bir başka hususiyet de yazdığı tarihlerdir. Bu tarihler içerisinde Şeyh Abbas'ın ölüm tarihi (1218/1803-4), Sersem Ali Baba Dergâhı'nın Harman Kapısı üzerine inşa edilen köşk tarihi (1217/1802-3), Serakin'de Vardar Nehri kenarına çekilen kaldırım tarihi (1232/1816-17) ve yine aynı tarihte ve yerde bir güz günü Vardar Nehrinin taşması sonucu oluşan hasarı anlatan bir tarih manzumesidir. $\mathrm{Bu}$ taşkında her taraf sularla dolmuş; Tuna Nehri gibi Vardar taşmış, Papaz Köprüsü yıkılmış, Sularcı Köprüsü üzerinden sular aşmıştır:

Her yaña seller akıp yüridi

Taşdı karada enhâr ne kim var

Tuna menendi oldı vü taşdı

Etrâfin aldı ol nehr-i Vardâr

Şehrüñ içinde nehr-i kebîr hem

Geldi acâ ib heybetle ey yâr

Cisr-i Papaz nâmıyla müsemmâ

Kapdı yirinden gitdi sebukbâr

Sularcı Köprüsi üzresinden

Akup giderdi ol gül haberdâr 


\section{Sonuç}

Saîd, 18. yüzyılın ikinci yarısında bugünkü Makedonya'nın Kalkandelen, Gostivar şehirleri civarında doğmuş 19. yüzyılın ilk çeyreği; 181822 yılları arasına kadar hayatta olan bir şairimizdir. Klasik kaynaklarda kendisine yer bulamamıştır. Bu yüzden hayatına ait ulaşabildiğimiz bilgiler elimizdeki şiirlerinden çıkarabildiğimiz sonuçlardan hareketledir.

Saîd, Bektaşî dervişidir. Abbas Baba onun ilk mürşididir. Recep Paşa'nın desteğini görmüştür. Şiirlerinin konusu içerisinde tasavvuf önemli bir yer tutar. Yaşadığı bölgeye ve döneme ait gerek şehrengiz türündeki şiirlerinde, gerek tarihlerinde ve gerekse medhiyelerinde devrin ve bölgenin fizikî, sosyal ve tarihî dokusuna dair birçok hususa 1şık tutacak bilgiler barındırır.

Saîd şiir geleneği içerisinde halk şiiri ile divan şiiri arasında sayılabilecek bir yerde durur. Şiirlerinin nazım şekli, türü ve şiirlerinde kullandığ1 vezinleri bunun önemli göstergeleridir. Şiirlerinde Rumeli'ye has söyleyişi dikkat çeker. Devrine göre sade bir dil kullandığını söylemek mümkündür. Şiirleri içerisinde yer alan Farsça manzumeleri onun Farsçaya vukufiyetini gösterir. Muamma tarzındaki kimi nükte ve cevapları da şairin bu alandaki maharetini yansıtır.

\section{Kaynaklar}

AYDEMİ, Yaşar-Abdülkadir Hayber (2007), Makedonya Kütüphaneleri Türkçe Yazma Eserler Katalogu, Ankara: TIKA Yayınları.

KALAFAT, Yaşar (1998), “Bedri Noyan Dedebaba ve Balkanlarda Bektaşilik", Türk Kültürü ve Hacıbektaş Velî Araştırma Dergisi, s. 81-98. Makedonya Millî Kütüphanesi OMCT I/150. 


\section{SAÎD'İN ŞIIIRLERINDEN ÖRNEKLER}

Mefâillün mefâîlün mefâîlün mefâîlün

Gel ey tâlib olan bûy-1 nesîm-i vasl-1 dildâra

Zuhûrı mebde-i bâğ-1 resûl-i Kibriyâ'dandur

Anuñ zevk u safâsından irişe behre ger dirsen

Tutup dâmân-ı evlâdı 'Ali'ye ilticâdandur

İmâm-1 evvel ol şâh-1 velâyet sâki-i Kevser

Dinildi "lâ-fetâ" medhinde bir nûr-1 Hüdâ'dandur

İmâmeynüm dahi Şebbîr ü Şebber melce'üm dâ'im Muhabbet zevki göñlümde sebât-1 müctebâdandur

Gözüm nûrı benüm mutlak Hüseyn-i ber-güzîd ol şâh Yezîd'e la 'netüm her dem o kahr-1 Kerbelâ'dandur

Felekde neyyirân şermende vech-i pür-ziyâsından Dilüm mihriyle tezyîn olduğı Zeyne'l-abâ'dandur

Muhammed Bâkır ol mâhum tulû' -1 âfitâbâsâ Ki kalb-i sâlike şems-i hakîkat bü'l-vefâdandur

İmâm u rehberüm hem Ca fer[î] mezheb-güşâ geldi

Tarîkat râhınuñ vüs' 1 bize ol reh-nümâdandur

İmâm-1 heftümîn ol nûr-1 'âlem Mûsi-i Kâzım İrişür 'âşıkâna lutf-1 pâki pür-'atâdandur

Mukırrem cân u dilden men garîb zât-ı a lâya Rızâya ser-nihâdum var 'Ali Mûsî Rızâ'dandur

Niçe üftâde dil-efkâr olupdur zülfine ber-dâr İdenler münkiri inkâr Takî'ye iktidâdandur

Takî bir ma 'den-i sırr-1 velâyet kân-1 gevher kim İrür mir'ât-1 kalbe rûşenâ ahsen-likâdandur İmâm-1 'Askerî ol mahrem-i râz-1 ulûhiyyet Virür dertlülere dermân çü zât-1 pür-sehâdandur 
Sa î̀üm var niyâzum mihri-i sâhib-zamânumdan

Bu ednâ kuluñı redd eyleme kim bir gedâdandur (Cönk s. 5)

\section{1'li hece}

Ahbâb ile bir gün sohbet iderken

Gönlüme bir 'aceb safâdur geldi

Gezüp dil mülkini seyrân iderken

Cân kulagına bir hoş sadâ geldi

Bir sadâ ki şevki irişdi câna

Ol zevküñ takrîri gelmez lisâna

Hayret ile bakar iken her yana

Erenler nişânı sancak göründi

Görince ta 'zîma kıldık kıyâmı

'Aceb kimdür didük bunuñ imâmı

Anı gördüm göñlümüñ dilârâmı

Şeyh Eyyûb Efendi kendidür geldi

Dizilmiş erkân ile önde dervîşler

Kimi kudûm çalar kimisi zencler

Hû ismini dilde izhâr iderler

'Ali gibi heybet salarak geldi

At üstünde arslan gibi oturmış

Çifte turasını hû ile dizmiş

Naz'rile dilleri vecde getürmiş

Şeyh Mustafâ Baba'nuñ gevheri geldi

Kendisi bir erdir hem erzâdedür

Pîr 'Abdulkâdir'in gonca gülidür

Şeyh Abbas Baba'nuñ sırr-1 dilidür

Dil mülküne sultân olanum geldi

Erenlerden budur niyâzum her-gâh

Himmetleri olsun Sa îde hem-râh

Şehr-i Pirizren'de sâhib-i dergâh

Tarîk-i Kadrî'nüñ bir şâh[1] geldi (Cönk s. 7) 


\section{Târîh Sersem 'Ali Baba Dergâhında Bâb-1 Hırmen Üzre Olan Köşk}

Fâilâtün fâilâtün fâilâtün fâilün

Hoş temâşâgâh 'uşşâka bu kasr-1 dil-güşâ

Gel teferrüc eyle dilde bul sürûrı 'ârifâ

Şâh 'Ali Sersem Baba Dergâhı bir cennet misâl

Kasr ile cümle müzeyyen yirde bu Firdevs-hevâ

Bâb-1 Hirmen üzre gelmiş dâr-1 mihmâna karîb

Bu mesîregâh-1 dil-keş cây-1 ra 'nâ pür-safâ

Hüzn ü gamdan dil rehâ-yâfte ola dirseñ ${ }^{5}$ eger

Gel 'urûc eyle bu zîbâ hûb mekâna dil-berâ

San hizâsında nesîmüñ bu makâm-1 dil-pezîr

Her seherlerde ziyâret eylemekde dâ'imâ

Bir yaña sahrâ-yı belde cümleten seyrindedür

Bir yaña gelmiş dırahtân eyle memlû ravzahâ

Seyyid 'Ali Dede himmet eyledi ol pâk-nijâd

Sâhibü'1-hayrât Recep Paşa durur ol pür-sehâ

Bir muhibb-i Murtazâ' dur âl u evlâd bendesi

Zât-1 pâki ırk-1 hâsı bulmaya aslâ fenâ

Gel Sa îdî dilde târîh söyle çün buldı vücûd

Böyle bir kasr-1 müferrih medhe lâyık ey dilâ

Sene $1217 / 1802-3$

(Cönk s. 13)

\section{Gazel Der Medh-i Serakin}

Mefâîlün mefâîlün mefâîlün mefâîlün

İricek nev-bahâr faslı gönüülleri güşâd eyler

Gelür nutka kamu murgân zebân ile senâ eyler

Bu demde tâlib-i bâde getürüp yârını yâde

Olurlar gamdan âzâde mekânın ${ }^{6}$ murgzâr eyler

${ }^{5}$ Metinde "dirsen" okunacak biçimde yazılmıştır.

${ }^{6}$ Metinde kelime "mekânuñ" okunacak biçimde yazılmıştır. 
Olar kim terk ide varın irür hoş-bûyına yârin

Görür mahbûbın âsârın cihânuñ medhini söyler

Bugünlerde mesîregâh gönül arzû kılup nâgâh

Bulup bir hoş-zebân hem-râh ki her dem hasb-i hâl söyler

Duhâ vakti süvâr olduk ol 'âlî râha yüz sürdük

Sürûr ile revân olduk öterdi çevre bülbüller

İrişdük şol yire ey yâr ki her dem göñül arzûlar

Kamu etrâfa çemenzâr döşenmiş sebz hâlîler

Degüldür vasfını imkân teferrücgâh her 'irfân

Ne yaña ${ }^{7}$ eyleseñ seyrân irür bir gûne cümbüşler

Donanmış her yaña eşcâr ihâtâ eylemiş enhâr

Kuşatmış bir yanın ${ }^{8}$ Vardar gice gündüz akup çağlar

Hudâvendî bir âlî-şâh işit sözümi ol âgâh

Anuñ pâyine şems ü mâh kılur minnet süre yüzler

Anı vasf itme mîm ol sen çü haddüñ yok otur epsem

Anuñ mehdinde kalur kem dirilse niçe Câmîler

Kurulmuş yüce bir eyvân ider 'âlemleri seyrân

Derûnda mânend-i şâhân sa âdetle durur begler ${ }^{9}$

Birisi Fahri Yûşân'dur ki ol kâmil-i insândur

Mufaddal beyne'l-akrândur tarîkatda odur rehber

17

Birisi 'Abdurahmân'ı bulup mesned-i şâhânı İder derdlere dermânı 'adâlet-bahşını söyler

Cemâli nûr-1 Yezdân'dur Hak'uñ lutfına bürhândur

Bize bir mahz-1 ihsândur vücûda geldi 'âdiller

Biri Hifzî ol 'âlî-şâh ider gibta felekde mâh

Dehânından anuñ hergâh akar dürr ile gevherler

\footnotetext{
${ }^{7}$ Metinde kelime "yana" okunacak şekilde yazılmıştır.

${ }^{8}$ Metinde kelime "yanuñ" okunacak şekilde yazılmıştır.

${ }^{9}$ Misrada vezin aksiyor.
} 
Birisi Şâh Velî'dür sehâda sanki 'Ali'dür Şecî'ler içre vâlîdür sözi arslan gibi gürler

Biri Mîr Hasan ol şâh çeker havfın ${ }^{10}$ olan gümrâh Aña her dem ola hem-râh 'avn-i Şâh 'Ali Haydar

İrişdi gözüme bir dem ulu zâtı sezer âdem

Celâleddîn ol mîrüm şakır bülbül gibi söyler

İlâhî câvidân eyle kamusını sa âdetle

Sehâvetle 'adâletle olalar dâ'imâ yekser

Ol eyvânuñ saña vasfın ${ }^{11}$ ne mümkin eyleye şerhin ${ }^{12}$

Anuñ cismin dahi resmin ${ }^{13}$ derilse niçe şâ 'irler

Bir etrâfı dahi cümle donanmış otalar birle

Mukîm olmış merâtible tevâbi 'ler bahâdırlar

Bu mevzi' dilde bir köydür Serâkin'le müsemmâdur

Ne köy san şehr-i a'zamdur gelicek anda vâlîler

Ko etrâf aña muhtâc toyunur anda niçe aç

Sezâdur vire aña baç Sa îd şehr ü gerek köyler (Cönk s. 16-17)

\section{Der Medh-i Kalkandelen}

Fâilâtün fâilâtün fâilâtün fâilün

Mazhar-1 lutf-1 Hudâ'dur bil dilâ Kalkandelen

Mirsad-1 sıdk u safâdur 'âşıka Kalkandelen

Menba '-1 nûr-1 șerî'at medhal-i sırr-1 tarîk

Mahzen-i genc-i hakîkat 'ârifâ Kalkandelen

Hoş nazar itmiş ezelden şânına ol zü'l-kemâl

Eylemiş tezyîn her yanuñ senüñ sâhib-cemâl

Kudretinden câri ırmağlar be san âb-1 zülâl

Ger saña mânend yok dirsem sezâ Kalkandelen

\footnotetext{
${ }^{10}$ Metinde kelime "havfuñ" okunacak şekilde yazılmıştır.

${ }^{11}$ Metinde kelime "vasfuñ" okunacak şekilde yazılmıştır.

${ }^{12}$ Metinde kelime "şerhüñ " okunacak şekilde yazılmıştır.

${ }^{13}$ Metinde kelime "resmüñ" okunacak şekilde yazılmıştır.
} 
Nev-bahâr faslı irişdükde açılur gülleri Her yañadan zâr idüben ötüşür bülbülleri Cümle etrâfı mesîregâh müferrih yerleri Her ne deñlü medh iderlerse revâ Kalkandelen

Bir 'aceb münbit-i sahrâ yir kamu halk toyunur Nâmı dillerde bahâdırlıkla dâ'im söylenür Böyle bir sahrâsı hem var belde nâdir bulunur Kırk iki dirler zemînüñ arzına Kalkandelen

Bir yañadan hâfızuñdur ${ }^{14}$ Şâh 'Ali Sersem Baba Sûy-1 bâlâda nigehbânuñ durur Koyun Baba Bir yañadan âsımuñ hâcet-revâ Yarar Baba Himmet-i merdân bilüpdür dilberâ Kalkandelen

İbtidâ dergâh açmış ol Sinânî erleri Hoş müferrihgâh ol sultânların makâmları Himmet ile şâd ideler bende-i nâçîzleri Sırra mazhardur bilâ-şek tâlibâ Kalkandelen

Çârşu-yı bâlâda evvel maksud-ı cânân imiş Âsitâne eyleyen Mînû Baba uryân imiş Oğlu Mahmûd ile Abbâs u Ganî irfân imiş Sâlik-i seyr-i sülûka reh-nümâ Kalkandelen

19

Sâ'atüñ kurbunda gelmiş Şeyh 'Ali kılmış karâr Zikr ü esmâ ile meşhûr menzile irmiş bular Hem civârında anuñ Mansûr Efendi yâdigâr Nâzır olmışdur saña ey hoşlikâ Kalkandelen

Çârsû zîrinde ol Şeyh Süleymân-1 latîf Mesken ü me'vâ idinmiş ol yiri zât-1 şerîf Zîr-i kurbında anuñ yügrügi Mehemmed zarîf Ârzulayup seni gelmiş imdada Kalkandelen

\footnotetext{
${ }^{14}$ Metinde kelime "hâfızındur" okunacak şekilde yazılmıştır.
} 
Eski Câmi üñ civârı dört yoluñ başı mekân Olmış ol sultâna merkez sanki kurmış bir divân Tâ zi-Bağdâd bir dem içre irişür feryâd-resân Böyle bir zâtlar saña itmiş vefâ Kalkandelen Şeyh 'Ali dîger hizâsında hamâmuñ meşhedi Nûr ile olmış münevver zât-ı pâkin merkadi Niçe bî-çârelerin olmış mahall-i maksadı Nûr-1 Ahmedle olupdur pür-ziyâ Kalkandelen

Sûy-1 fevkınde anuñ Mehmed Efendi çün asâ Câmi '-i Sâlih Çelebi havlısı cennetasâ Ger celâle gelse oynar sırr-1 Şâh 'Abdal Mûsâ Gül cemâliyle münevver dâ'imâ Kalkandelen

Bir nikâb-keş zât imiş dirler o şâh-1 muhterem Hulk-1 Ahmed ile tezyîn eylemiş ol zü'l-kerem Hamdulillah kim nasîb oldı aña yüzler sürem Ol saña gelmiş misâfir gâlibâ Kalkandelen

Nev-zuhûr Baba dimişler bir velînüñ nâmına Gelmiş oturmış 'Ali Sersem Baba'nuñ yanına Hoş muhît olmış çemenzâr meşhed[i] etrâfına Evliyâlar himmeti kılmış gınâ Kalkandelen

20

İftihâr it gel senüñle Rûm ili çıkmaz başa Eylemişdür 'adl ile tezyîn seni Receb Paşa Ni ' metin ${ }^{15}$ bezl eylemiş insâna hayvâna kuşa Irk-1 pâki câvidân olsun saña Kalkandelen İdemezsin ey Sa 'îd medhin ${ }^{16}$ kasîr eyle kelâm Kim bu şehrüñ vasfını itmek ne mümkin bi't-tamâm Hem direm çârsû-yı bâlâ san Mısır'dur ve's-selâm Âb u hevâsı müferreh dil-güşâ Kalkandelen (Cönk s. 18-20)

\footnotetext{
${ }^{15}$ Metinde kelime "ni 'metüñ" okunacak şekilde yazılmıştır.

${ }^{16}$ Metinde kelime "medhüñ" okunacak şekilde yazılmıştır.
} 